\author{
K.S. Turebekova, I.M. Oskembekov, Zh.S. Oskembekova, \\ G.L. Katkeeva, E.M. Zhunussov \\ Zh. Abishev Chemical-Metallurgical Institute, Karaganda, Kazakhstan \\ (E-mail: kakosh-94@mail.ru)
}

\title{
Study and development of the process scheme of barytic raw material leaching
}

\begin{abstract}
Continuous growth of demand for crude ore leads to accelerated development of high-grade deposits and to putting into operation the impoverished deposits. Consequently specific yield of industrial waste for the unit of products at all the stages of productionincreases.Developmentofleachingschemesofbarium-containing waste is the purpose of the given article. There search object is barium-containing waste produced at flotation enrichment of barium-polymetal ores. The experiments on water leaching of barium-containing waste in the presence of ammonium fluoride were carried out by means of the design of experiments. In order to research leaching of barium-containing waste, three factors were chosen, namely, leaching temperature $(\mathrm{T})$, leaching time $(\tau)$ and percentage of the initial solution on ammonium fluoride $(\mathrm{C})$. The mathematical model of the process was developed and optimal conditions were determined for leaching barium-containing waste that provided production of desilicated concentrate of compound, mass \%: $\mathrm{SiO}_{2}-1.9 ; \mathrm{BaSO}_{4}-67.3 ; \mathrm{Fe}-8.4$; $\mathrm{Zn}-1.09 ; \mathrm{Pb}-0.91 ; \mathrm{Cu}-0.36$. Under laboratory conditions, the scheme of barium-containing waste leaching was developed. Studies of barium-containing waste leaching allowed detecting partial dependence of silicon extraction into the solution on the temperature, time of leaching and concentration of solution. On the basis of significant partial dependencies, the mathematical model of the process was developed by means of which the optimum conditions for leaching were determined. Two products were produced, namely, the ammonium hexafluorosilicate solution and the chemically enriched desilicated barite concentrate.
\end{abstract}

Keywords: barium, barium-containing waste, fluoride technology, leaching, silicon, ammonium hexafluosilicate, desilication.

\section{Introduction}

Demand for crude ore constantly increases, which leads to accelerated resource recovery and to developing deposits of a low grade. Accelerated development of deposits leads to increasing specific yield in industrial waste per unit of output. The main problem of barium-containing waste is absence of technology and inefficient conventional development methods. The problem of development of barium-containing waste is due to the absence of an efficient application of the conventional treatment technology: acid leaching in the context of the complex mineral composition. Final rejects of treatment plants stored in the tailing dumps belong to barium-containing waste. Disposal are as occupy significant spaces and are the source of pollution of soil, air, and water basins with heavy metals and barite powder.

Treatment of waste of barium-containing poly metal ores has big economic potential. It contains up to $40 \%$ of $\mathrm{BaSO}_{4}, 0.4 \%$ of $\mathrm{Cu}, 0.8 \%$ of $\mathrm{Zn}, 0.6 \%$ of $\mathrm{Pb}$ by which this waste may be classified as the industrial poly metal barite raw material. It has an advantage over the mineral raw material because expenses for extraction and refinement are not necessary. Waste stocks are significant: up to twenty million tons.

Dissociation of ore minerals with silicon-containing minerals of waste material is a problem of treating this type of raw material. A step-ahead solution of the problem is uncovering a raw material by chemical methods, and, in particular, by fluorine-ammonium method at which in the process of water leaching in presence of ammonium fluorine, silicon goes to the liquid phase from the solid one, because of formation of water-soluble ammonium hexafluorosilicate. The given method has energy consumption advantages over the fluorosulfate method of high-silicon raw material extraction that requires baking at a temperature of up to $400{ }^{\circ} \mathrm{C}$.

The article is devoted to the search for a problem of utilization of barium-containing waste. The solution of the given problem is of ecological and economic significance. The solution of the problem would allow improving the ecologic situation around the enterprises producing the given type of waste.

Water leaching of the barite raw material in the presence of ammonium fluorine and determination of optimal conditions of the process are the main tasks of the article. 


\section{Raw material treatment and desilication methods}

Hydrochemical and thermochemical processes became ingrained in complex treatment of the highsilicon raw material. The main operation is uncovering the raw material by a chemical interaction with the silicon oxide, that the raw material contains, and leaching.

So, alkaline autoclave desilication of high-silicon copper concentrates would lead to enrichment of initial copper concentrate by all the metals and sulfur, prevent difficulties of copper melting by the modern technological schemes [1].

Hydrochemical autoclave method is applied while extracting alumina from the high-silicon raw material [2]. Its essence is concluded in autoclave leaching of aluminosilicate raw material by strong solutions of sodium hydrate in the presence of lime. Aluminate and sodium silicate pass to the solution, then sodiumcalcium hydro-silicate precipitates from the solution. Conditions for high extraction of alumina are superabundance of the free caustic alkali in the solution, a high temperature, and a high concentration of the alkali solution.

It should be mentioned that the given desilication methods while treating high-silicon raw material require the corresponding instrumentation and high measures on safety technique because of application of leaching of the concentrated alkali solution and running the process at high temperatures and pressure.

The most efficient reagents for uncovering silicate bases of high-silicon raw material are elemental fluorine and fluorine hydride, and ammonium fluoride. However, there are several problems, restricting application of $\mathrm{F}_{2}$ and $\mathrm{HF}$ for these purposes. In particular, the use of elemental fluorine will require creation of additional production of fluorine that will increase expenses for final product. Application of HF, as well as of $\mathrm{F}_{2}$, will lead to generation of the toxic gas $\mathrm{SiF}_{4}$ that requires special work and utilization conditions. Therefore, the use of fluorides and bifluorides, ammonium for running desilication is more technologically profitable [3].

In the study [4], we tried the method that includes baking silicon-containing material by ammonium bifluorine at a temperature of $200{ }^{\circ} \mathrm{C}$ and removal of generated ammonium hexafluorosilicate at a temperature of $400{ }^{\circ} \mathrm{C}$. The exit gas consisting of $\left(\mathrm{NH}_{4}\right)_{2} \mathrm{SiF}_{6}$, is absorbed by an ammonia water resulting in generation of alumina consisting of precipitates separated by filtration. After separation of alumina, the solution is evaporated. The solid residue consisting of the fluoride and bifluoridemix is baked at a temperature of 180 $200^{\circ} \mathrm{C}$ with capturing escaping ammonia. Ammonia bifluoride produced after burning is led to burning the next portion of the silicon-containing material.

The most rational method of desiliconization of a silicon-containing material is the hydrochemical method [5] according to which the silicon-containing material is leached by the mix of bifluoride $\left(\mathrm{NH}_{4} \mathrm{HF}_{2}\right)$ and fluoride $\left(\mathrm{NH}_{4} \mathrm{~F}\right)$ ammonium at a temperature of $100{ }^{\circ} \mathrm{C}$ within 3 hours. Then, highly soluble $\left(\mathrm{NH}_{4}\right)_{2} \mathrm{SiF}_{6}$ is separated by filtration of slurry sludges formed at the $\mathrm{pH}$ 5.5-6.0 consisting of hexafluoraluminum $\left.\left(\left(\mathrm{NH}_{4}\right)_{3} \mathrm{AlF}_{6}\right)\right)$ and hexafluorferrate $\left(\left(\mathrm{NH}_{4}\right)_{3} \mathrm{FeF}_{6}\right)$ ammonium, calcium fluorine, magnesium, and other compounds. The $\left(\mathrm{NH}_{4}\right)_{2} \mathrm{SiF}_{6}$ water solution interacts with ammonia water at a temperature of $20-80{ }^{\circ} \mathrm{C}$ with sludging of $\mathrm{SiO}_{2}$.

In order to decrease material and energy expenses the method of hydrochemical leaching of high-silicon material has been experimentally studied in this publication, in particular, leaching of the silicon-containing barite raw material by the ammonium fluoride solution.

\section{Justification of studies of leaching barite raw materials}

Chemical enrichment of barium-containing waste involves its desilication. There are several methods of chemical desilication. One of the methods consists in baking the silica-containing material with ammonium bifluoride at a temperature of $200^{\circ} \mathrm{C}$ and removal of generated ammonium hexafluorosilicate at a temperature of $400{ }^{\circ} \mathrm{C}$. We tried this method in the study [6]. The other method consists in processing the material by the ammonium fluoride solution at a temperature ofapproximately $100{ }^{\circ} \mathrm{C}$. In such event, silicon is connected with operating reagent into ammonium hexafluorosilicate and passes to solution. The second method differs from the first one by smaller energy consumption, simpler instrumentation, and a smaller number of technological operations demands for less number of technological operations.

With the view to determine efficiency of the given desilication method we carried out studies of leaching the barite raw material by means of the ammonium fluoride solutions corresponding to the scheme shown in the Figure 1. 


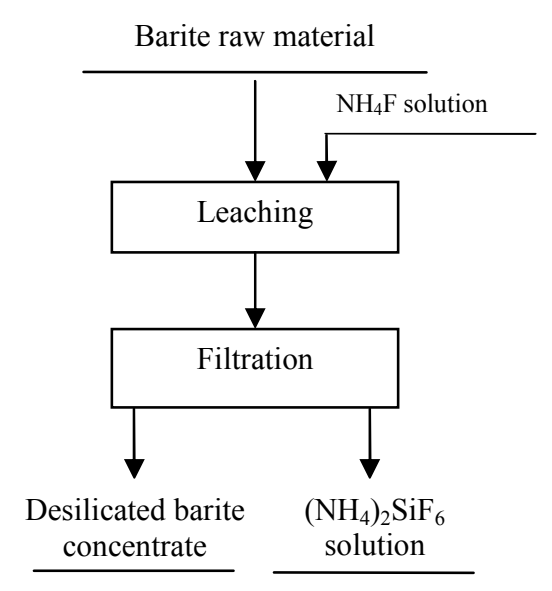

Figure 1. Technological scheme of barite raw material leaching

Leaching the barite raw material may be presented as a corresponding mathematical model. In order to create this model, it is necessary to study influence of the different factors on leaching with involving the method of experiment planning [7].

Studies on leaching are carried out on the waste of flotation enrichment of barite-polymetal ores of the Karagaily deposit-barite raw material of composition, mass. \%: $\mathrm{SiO}_{2}-40.0 ; \mathrm{BaSO}_{4}-37.0 ; \mathrm{Al}_{2} \mathrm{O}_{3}-5.3$; $\mathrm{Fe}-4.6 ; \mathrm{S}-6.8 ; \mathrm{Zn}-0.6 ; \mathrm{Pb}-0.5 ; \mathrm{Cu}-0.2$.

In order to study the process of leaching barium-containing waste three factors are chosen, namely, leaching temperature (this factor is marked as $T$ ), leaching time $(\tau)$, and percentage of the initial ammonium fluoride solution $(C)$. The factor change range is shown in Table 1.

$\mathrm{Tab} 1 \mathrm{e} 1$

\section{Factors and levels of their variation for studying the process of barium-containing waste leaching}

\begin{tabular}{|l|c|c|c|c|c|}
\hline \multirow{2}{*}{\multicolumn{1}{|c|}{ Factor }} & \multicolumn{5}{|c|}{ Level } \\
\cline { 2 - 6 } & 1 & 2 & 3 & 4 & 5 \\
\hline T, Temperature, ${ }^{\circ} \mathrm{C}$ & 80 & 85 & 90 & 95 & 100 \\
\hline$\tau$, Time, min. & 30 & 60 & 80 & 100 & 120 \\
\hline$C$, Solution percentage, $\%$ & 10 & 20 & 30 & 35 & 40 \\
\hline
\end{tabular}

For each experiment, a charge of barium-containing waste of a certain weight was taken. Then, it was put into the stainless thermostat container with the ammonium fluoride solution, and leaching was carried out under a set of conditions with interfusion.

On expiration of leaching time, solids and liquids were separated by vacuum filtration. Precipitates on the paper filter were washed off with distilled water. After drying and weighing it was analyzed for silicon containing by the chemical method.

Based on the data obtained from the chemical analysis, extraction of $\alpha$-silicon into the solution was determined. The results are given in Table 2.

Table 2

Influence of the factors of leaching barium-containing wastes on extraction of silicon into the solution

\begin{tabular}{|c|c|c|c|c|c|}
\hline \multirow{2}{*}{ No. of experience } & \multirow{2}{*}{${ }^{\circ} \mathrm{C}$} & \multirow{2}{*}{$\tau, \min$} & \multirow{2}{*}{$\mathrm{N}, \%$} & \multicolumn{2}{|c|}{ Extraction of silicon into the solution, \% } \\
\cline { 5 - 6 } & 2 & 3 & 4 & $\alpha \mathrm{E}$ & \multicolumn{2}{c|}{} \\
\hline 1 & 80 & 30 & 10 & 35.02 & 37.15 \\
\hline 1 & 80 & 80 & 30 & 40.61 & 40.09 \\
\hline 2 & 80 & 60 & 20 & 37.80 & 39.14 \\
\hline 3 & 80 & 120 & 40 & 41.88 & 41.18 \\
\hline 4 & 80 & 100 & 35 & 42.73 & 40.68 \\
\hline 5 & 90 & 30 & 30 & 78.06 & 76.74 \\
\hline 6 & 90 & 80 & 20 & 79.85 & 80.00 \\
\hline
\end{tabular}


Study and development of the process scheme ...

Continuation of Table 2

\begin{tabular}{|c|c|c|c|c|c|}
\hline 1 & 2 & 3 & 4 & 5 & 6 \\
\hline 8 & 90 & 60 & 40 & 86.96 & 80.09 \\
\hline 9 & 90 & 120 & 35 & 83.52 & 82.69 \\
\hline 10 & 90 & 100 & 10 & 80.45 & 79.62 \\
\hline 11 & 85 & 30 & 20 & 57.12 & 59.68 \\
\hline 12 & 85 & 80 & 40 & 59.26 & 63.80 \\
\hline 13 & 85 & 60 & 35 & 58.70 & 62.67 \\
\hline 14 & 85 & 120 & 10 & 61.55 & 63.07 \\
\hline 15 & 85 & 100 & 30 & 62.11 & 93.10 \\
\hline 16 & 100 & 30 & 40 & 92.55 & 97.99 \\
\hline 17 & 100 & 80 & 35 & 96.70 & 93.83 \\
\hline 18 & 100 & 60 & 10 & 93.12 & 99.67 \\
\hline 19 & 100 & 120 & 30 & 99.17 & 97.85 \\
\hline 20 & 100 & 100 & 20 & 97.05 & 87.90 \\
\hline 21 & 95 & 30 & 35 & 86.20 & 89.87 \\
\hline 22 & 95 & 80 & 10 & 87.55 & 90.82 \\
\hline 23 & 95 & 60 & 30 & 86.68 & 93.19 \\
\hline 25 & 95 & 120 & 20 & 90.21 & 93.82 \\
\hline
\end{tabular}

Supposing that the study function was extraction of silicon from barium-containing waste into the solution we sampled experimental data by levels within factor. The selected experimental values of partial functions are given in Table 3.

Table 3

Experimental values of the particular functions on extraction of silicon to the solution

\begin{tabular}{|c|c|c|c|c|c|c|}
\hline \multirow{2}{*}{ Function } & \multicolumn{5}{|c|}{ Levels } & \multirow{2}{*}{ Average value } \\
\cline { 2 - 6 } & 1 & 2 & 3 & 4 & 5 & 72.33 \\
\hline$\alpha_{1}$ & 39.61 & 59.75 & 81.77 & 87.79 & 95.72 & 72.33 \\
\hline$\alpha_{2}$ & 69.79 & 72.65 & 72.79 & 74.13 & 75.27 & 72.33 \\
\hline$\alpha_{3}$ & 71.54 & 72.41 & 73.33 & 73.57 & 73.80 & \\
\hline
\end{tabular}

By the experimental values of the functions the dot diagrams of a partial dependence of extraction of silicon into the solution on examined factors were constructed. They are shown in Figure 2.
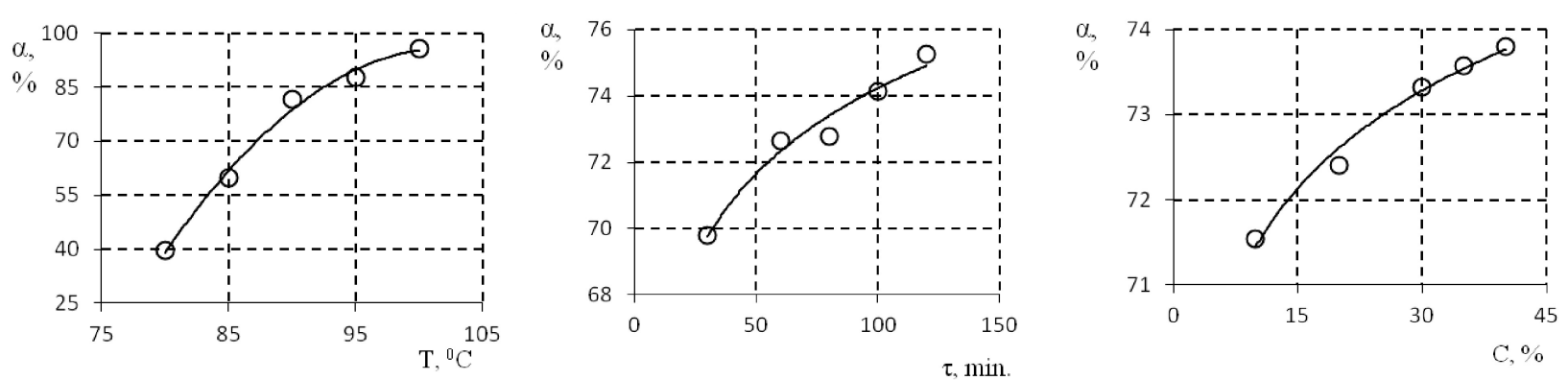

Figure 2. Dependencies of silicon extraction into the solution

By the point data, approximating functions were selected to describe dependence of silicon extraction into the solution on the studied factors of leaching:

$$
\begin{gathered}
\alpha_{1}=-0.1155 T^{2}+23.59 T-1109.0 \\
\alpha_{2}=3.716 \ln (\tau)+57.11 \\
\alpha_{3}=1.666 \ln (C)+67.61
\end{gathered}
$$

According to those equations the values of partial functions were calculated and their average values were determined. The calculation data are given in Table 4. A minor deviation of the average calculated values from the general average of the experimental value testifies that equations and dot diagrams are closely matched. 
Calculated values of partial functions by extraction of silicon into the solution

\begin{tabular}{|c|c|c|c|c|c|c|}
\hline \multirow{2}{*}{ Function } & \multicolumn{5}{|c|}{ Levels } & \multirow{2}{*}{ Average value } \\
\cline { 2 - 6 } & 1 & 2 & 3 & 4 & 5 & 72.77 \\
\hline$\alpha_{1}$ & 39.00 & 61.66 & 78.55 & 89.66 & 95.00 & 72.92 \\
\hline$\alpha_{2}$ & 69.75 & 72.32 & 73.39 & 74.22 & 74.90 & 72.92 \\
\hline$\alpha_{3}$ & 71.45 & 72.60 & 73.28 & 73.53 & 73.76 & \\
\hline
\end{tabular}

Then, the coefficient of nonlinear multiple correlation and the value of the produced partial dependences were determined. The results are given in Table 5.

Table 5

The $R$ coefficient of correlation and its relevance $t R$ for partial functions in extraction of silicon into the solution

\begin{tabular}{|c|c|c|c|}
\hline Function & $\mathrm{R}$ & $\mathrm{t}_{\mathrm{R}}$ & Function significance \\
\hline$\alpha_{1}$ & 0.99 & 145.9 & Significant \\
\hline$\alpha_{2}$ & 0.98 & 38.5 & Significant \\
\hline$\alpha_{3}$ & 0.99 & 137.7 & Significant \\
\hline
\end{tabular}

The analysis of particular dependencies shows that in the matrix experiments leaching temperature exercises the greatest influence on the degree of extraction of silicon into the solution. So, extraction increases by $56 \%$ on average when temperature increases from $80^{\circ} \mathrm{C}$ to $100{ }^{\circ} \mathrm{C}$. Extraction increases throughout the entire studied interval tending to saturation.

Dependence of extraction of silicon on the time of leaching and on the concentration of ammonium fluoride is similar. However, they exercise less influence — in the studied time intervals and concentration increase of extraction of silicon averages 5 and $2 \%$, correspondingly.

The generalized multivariable equation for extraction of silicon into the solution made on the basis of relevant partial dependences looks like that:

$$
\alpha=\left(-0.1155 T^{2}+23.59 T-1109.0\right)(3.716 \ln (\tau)+57.11)(1.666 \ln (\mathrm{C})+67.61) 72.33^{-2} .
$$

This equation is a mathematical model of silicon extraction from barite raw material by leaching ammonium fluoride with a solution. The results (Table 2) that show the considerable relationship with experiment data $(R=0.99, t R=236.4)$ clearly demonstrate that this model is sufficient.

According to the developed model full extraction of silicon into the solution can be expected at a temperature of $95^{\circ} \mathrm{Cat}$ an ammonium fluoride solution concentration of $25 \%$ and duration of leaching the barite raw material of 80 minutes.

\section{Summary}

Studies of leaching barium-containing waste allowed getting particular dependences of extraction of silicon into the solution from temperature leaching time and concentration of solution. On the basis of relevant particular dependences the mathematical model of process is developed, by means of which the optimal leaching conditions are determined. Two products are derived, namely the solution ammonium hexafluorosilicate and the chemically enriched desilicated barite concentrate.

\section{References}

1 Шкодин В.Г. Щелочное обескремнивание сырья: монография / В.Г. Шкодин, Д.Н. Абишев, Н.С. Бектурганов. Алма-Ата: Наука, 1984. - 200 с.

2 Лайнер А.И. Производство глинозема / А.И. Лайнер. - М.: Металлургия, 1978. — 344 с.

3 Мельниченко Е.И. Процессы обескремнивания при переработке и обогащении минерального сырья гидрофторидом аммония / Е.И. Мельниченко, Д.Г. Эпов, Г.Ф. Крысенко, А.А. Овсянникова // Журнал прикладной химии. - 1996. - Т. 69 , Вып. 8. - С. 1248-1251.

4 Разработка способов извлечения редких и редкоземельных металлов при комплексной переработке углистых и золошлаковых отходов: отчет о НИР / ХМИ им. Ж. Абишева. — Караганда, 2012. — 79 с. — Инв. № 012 РК00846.

5 Римкевич В.С. Разработка гидрохимического метода обогащения зольных техногенных отходов предприятий теплоэнергетики / В.С. Римкевич, А.А. Пушкин, И.В. Гиренко // Фундаментальные исследования. — 2015. — № 2(23). — С. 51565160 . 
6 Разработка комбинированной химико-флотационной технологии переработки баритсодержащего техногенного сырья: отчет о НИР / ХМИ им. Ж. Абишева. — Караганда, 2015. - 67 с. — Инв. № 0215РК01978.

7 Малышев В.П. Вероятностно-детерминированное планирование эксперимента: монография / В.П. Малышев. - Алма-Ата: Наука, 1981. - 116 с.

\author{
К.С. Туребекова, И.М. Оскембеков, Ж.С. Оскембекова, Г.Л. Каткеева, Е.М. Жунусов
}

Бариттік шикізатты сілтілеу процесі схемасын ойлап табу және зерттеу

\begin{abstract}
Зерттеу нысаны барит-полиметалдық кенін флотациялық байыту кезінде алынған баритқұрамдас қалдықтар болып табылады. Мақаланың мақсаты - баритқұрамдас қалдықтарды сілтілеу схемасын ойлап табу. Жоспарлау әдісін қолдану арқылы баритқұрамдас қалдықтарды аммоний фторидінің қатысында сулы сілтілеу эксперименттері өткізілді. Баритқұрамдас қалдықтарды сілтілеу процесін зерттеу үшін үш фактор таңдап алынды - сілтілеу температурасы $(T)$, сілтілеу уақыты $(\tau)$ және аммоний фториді бойынша бастапқы ерітіндінің пайыздық концентрациясы $(C)$. Құрамы пайыздық өлшемде $\mathrm{SiO}_{2}-1.9 ; \mathrm{BaSO}_{4}-67.3 ; \mathrm{Fe}-8.4 ; \mathrm{Zn}-1.09 ; \mathrm{Pb}-0.91 ; \mathrm{Cu}-0.36$ болатын кремнийсіз концентрат алуды қамтамасыз ететін баритқұрамдас қалдықтарды сілтілеудің тиімді шарттары мен үрдістің математикалық үлгісі алынды. Лабораториялық шарттарда баритқұрамдас қалдықтарды сілтілеу схемасы жасалды. Баритқұрамдас қалдықтарды сілтілеу үрдісін зерттеу кремнийді ерітіндіден шығарудың температурадан, сілтілеу уақытынан және ерітінді концентрациясынан жеке тәуелділіктерін алуға мүмкіндік берді. Алынған жеке тәуелділіктер негізінде процестің математикалық үлгісі алынды. Оның көмегімен сілтілеудің тиімді шарттары анықталды. Екі өнім алынды. бірінші өнім аммоний гексафторосиликат ерітіндісі және екінші өнім - химиялық әдіспен байытылған кремнийсіз баритті концентрат.
\end{abstract}

Кілт сөздер: барит, барит құрамды қалдықтар, фторидтік технология, сілтілеу, кремний, аммоний гексафторосиликаты, кремнийсіздендіру.

\title{
К.С. Туребекова, И.М. Оскембеков, Ж.С. Оскембекова, Г.Л. Каткеева, Е.М. Жунусов Исследование и разработка схем процесса выщелачивания баритового сырья
}

\begin{abstract}
Объектом исследований являются баритсодержащие отходы, полученные при флотационном обогащении барито-полиметалических руд. Разработка схем выщелачивания баритсодержащих отходов является целью данной статьи. С использованием метода планирования проведены эксперименты по водному выщелачиванию баритсодержащих отходов в присутствии фторида аммония. Для исследования процесса выщелачивания баритсодержащих отходов выбраны три фактора — температура выщелачивания $(T)$, время выщелачивания $(\tau)$ и процентная концентрация исходного раствора по фториду аммония $(C)$. Получена математическая модель процесса, и определены оптимальные условия выщелачивания баритсодержащих отходов, обеспечивающие получение обескремненного концентрата состава, масс. \%: $\mathrm{SiO} 2-1.9$; $\mathrm{BaSO} 4-67.3$; $\mathrm{Fe}-8.4 ; \mathrm{Zn}-1.09 ; \mathrm{Pb}-0.91$; $\mathrm{Cu}-0.36$. В лабораторных условиях разработана схема выщелачивания баритсодержащих отходов. Исследование процесса выщелачивания баритсодержащих отходов позволили получить частные зависимости извлечения кремния в раствор от температуры, времени выщелачивания и концентрации раствора. На основании значимых частных зависимостей получена математическая модель процесса, с помощью которой определены оптимальные условия выщелачивания. Получены два продукта. Первый продукт раствор гексафторосиликата аммония и второй продукт - обогащенный химическим методом обескремненный баритовый концентрат.
\end{abstract}

Ключевые слова: барит, баритсодержащие отходы, фторидная технология, выщелачивание, кремний, гексафторосиликат аммония, обескремнивание.

\section{References}

1 Shkodin, V.G., Abishev, D.N., \& Bekturganov, N.S. (1984). Schelochnoe obeskremnivanie syria [Alkaline desilicification of raw materials]. Alma-Ata: Nauka [in Russian].

2 Layner, A.I. (1987). Proizvodstvo hlinozema [Alumina production]. Moscow: Metallurhiia [in Russian].

3 Melnichenko, E.I., Epov, D.G., Krysenko, G.F., \& Ovsyannikova, A.A. (1996). Protsessy obeskremnivaniia pri pererabotke i obohashchenii mineralnoho syria hidroftoridom ammoniia [Processes of desilicification during re-processing and enrichment of min- 
eral raw materials with ammonium hydrofluoride]. Zhurnal prikladnoi khimii. — Russian journal of applied chemistry, 69, 8, 12481251 [in Russian].

4 Razrabotka sposobov izvlecheniia redkikh i redkozemelnykh metallov pri kompleksnoi pererabotke uglistykh i zoloshlakovykh othodov: otchet o NIR /Development of methods for extracting rare and rare-earth metals during complex processing of coal and ash-and-slag wastes: a report on research] (2012). Zh. Abishev Chemical-Metallurgical Institute, Karaganda, 79, Inv. \# 012 RK00846 [in Russian].

5 Rimkevich, V.S., Pushkin, A.A., \& Girenko, I.V. (2015). Razrabotka hidrokhimicheskoho metoda obohashcheniia zolnykh tekhnohennykh othodov predpriiatii teploenerhetiki [Development of a hydrochemical method for enriching ash technogenic wastes of thermal power plants]. Fundamentalnye issledovaniia - Fundamental investigations, 2(23), 5156-5160 [in Russian].

6 Razrabotka kombinirovannoi khimiko-flotatsionnoi tekhnolohii pererabotki baritsoderzhashcheho tekhnohennoho syria: otchet o NIR [Development of a combined chemical-flotation technology for the processing of barite-containing man-made raw materials: a report on research] (2015). Zh. Abishev Chemical-Metallurgical Institute, Karaganda, 67, Inv. \# 0215 RK01978 [in Russian].

7 Malyshev, V.P. (1981). Veroiatnostno-determinirovannoe planirovanie eksperimenta [Stochaistic-deterministic planning of the experiment]. Alma-Ata: Nauka [in Russian]. 